\title{
THE INFLUENCE OF RAW MATERIAL GROWTH REGION, ANATOMICAL STRUCTURE AND CHEMICAL COMPOSITION OF WOOD ON THE QUALITY PROPERTIES OF PARTICLEBOARDS
}

\author{
Selahattin Bardak ${ }^{1, £}$, Gökay Nemli², Sebahattin Tiryaki ${ }^{2}$
}

\begin{abstract}
In the present study, the impact of raw material grown region on the physical, mechanical, surface properties and formaldehyde emission of the particleboard was investigated. Ailanthus altissima wood grown in Trabzon had longer fiber length and thicker fiber and trachea cell wall than those of the wood grown in Artvin. The highest amounts of lignin, ash, condensed tannin and solubility values were found in wood grown in Artvin. Ailanthus altissima wood grown in Trabzon had higher amounts of cellulose and hemicellulose than those of the wood grown in Artvin. Particleboards made from wood grown in Artvin had worse surface quality and mechanical strength properties than those of panels made from wood grown in Trabzon. On the other hand, the results showed that particleboards produced from wood grown in Artvin had lower thickness swelling and formaldehyde emision values than those of the panels produced from wood grown in Trabzon.
\end{abstract}

Keywords: Anatomical properties, chemical properties, formaldehyde emission, mechanical properties, surface roughness.

\section{INTRODUCTION}

Particleboard is a very popular engineered wood-based panel produced from wood particles, such as chips, sawmill, shavings, or sawdusts, and a synthetic resins. It is widely used in the production of furniture, interior decoration, cabinets, floor underlayment, home constructions, stair treads, table and counter tops and other industrial applications (Nemli and Demirel 2007). The most important quality indicators of particleboards can be specified as mechanical, physical and surface properties, and formaldehyde emission. The physico-mechanical properties of particleboards are very important in terms of their recommended use (Fernández et al. 2008). With regard to the surface roughness, it was mentioned that the surface roughness of the particleboard is highly crucial for coating applications, and any irregularities on the board surface may affect negatively the quality of the final product (Nemli et al. 2005). Another indication of quality and suitability of the particleboard is the formaldehyde emission, and in the study of Ayrilmis et al. (2016), it was reported that formaldehyde emitted from particleboards is one of the leading causes of indoor air pollution. Hence, formaldehyde emission from building materials such as particleboard is a vital issue required to be solved for building designers and researchers (Zhang et al. 2007).

\footnotetext{
${ }^{1}$ Department of Industrial Engineering, Faculty of Engineering and Architecture, Sinop University, Sinop, Turkey. ${ }^{2}$ Department of Forest Industry Engineering, Faculty of Forestry, Karadeniz Technical University, Trabzon, Turkey. •Corresponding author: sbardak@sinop.edu.tr
} 
Many investigations have been carrried out on the influence of raw material and production factors on the quality characteristics of particleboards. These factors studied are cutting tool geometry, crushing conditions, particle compaction, fine screen usage, and press closing time (Hizıroglu and Graham 1998, Hiziroglu et al. 2004), the use of wood bark and pine cone (Balanchet et al. 2000, Ayrilmis et al. 2009), formaldehyde/urea mole ratio, resin level, catalyst level and composition, post treatment and formaldehyde scavengers (Que et al. 2007), utilization of bagasse (Ghalehno et al. 2011), residue type and tannin content (Moubarik et al. 2013), pressing parameters such as times, temperatures, and pressures (Boon et al. 2013, Liu et al. 2015), the use of plasma treated wood particles (Altgen et al. 2015), log position (Muhcu et al. 2015), utilization of bamboo and rice husk (Melo et al. 2015), utilization of reed stem and canola (Brassica napus) straws (Kord et al. 2015, Kord et al. 2016), and the use of cotton (Gossypium hirsutum) stalks (Nazerian et al. 2016).

In this study, we aimed to reveal the relationship between the raw material growth region and particleboard quality characteristics such as flexural properties, internal bond strength (IB), thickness swelling (TS), surface roughness and formaldehyde emission of boards manufactured from woods grown in two different regions.

\section{MATERIALS AND METHODS}

Ten Ailanthus altissima (Mill.) Swingle trees were felled from private forests in

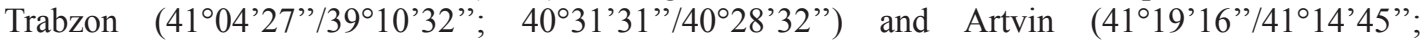
$\left.41^{\circ} 22^{\prime} 15^{\prime \prime} / 42^{\circ} 34^{\prime} 28^{\prime \prime}\right)$ cities of Turkey.

The age and diameter of the trees were 14 -years-old and $18 \mathrm{~cm}$, respectively. The bark of the logs was removed before chipping and all the trees were chipped using a ring type flaker after the foliage was trimmed. The chips were then reduced into smaller particles using a hammer mill. The chips were dried to 3\% moisture content in a dryer. The dried chips were classified into two sizes using a 3,0$1,5-0,5 \mathrm{~mm}$ openings vibrating screen for the core and face layers. The particles remaining between 3 and $1,5 \mathrm{~mm}$ sieves were used in the core layer, while the particles between 1,5 and 0,5 $\mathrm{mm}$ sieves were used in surface layers. In the subsequent process, urea formaldehyde resin (solid content: 65\%) was applied with a pneumatic spray gun. Based on the dry weight of the particles, $10 \%$ and $12 \%$ urea formaldehyde resin was separately applied for core and surface particles, respectively. It is important to say the adhesive type, the amount of adhesive and application conditions were kept equal for all boards. The ratio of the face thickness to the total thickness of a board, which is also known as the shelling ratio, was 0,40 for all samples. As a resin hardener, ammonium sulphate (concentration: 25\%) was applied in s proportion of $1 \%$ based on the solid amount of ure formaldehyde adhesive. No wax or any other additives were used for the particleboard production. Mats formed manually in a frame with a size of $550 \times 600 \mathrm{~mm}^{2}$ were pressed by using a temperature of $150{ }^{\circ} \mathrm{C}$ and a pressure of $2,5 \mathrm{MPa}$ for 6 min.A nominal thickness of $12 \mathrm{~mm}$ and an average target density of $0,75 \mathrm{~g} / \mathrm{cm}^{3}$ are used in the press of all panels. Two panel types of particleboard were produced and then the types were duplicated to have four experimental panels.

The produced experimental panels were conditioned at $20{ }^{\circ} \mathrm{C}$ and relative humidity of $65 \%$. Physical properties- thickness swelling (TS), (EN 317, 1993) (after 2 and $24 \mathrm{~h}$ immersion), - and mechanical properties-modulus of rupture (MOR), modulus of elasticity (MOE) (EN 310, 1993), and internal bonding strength (IB) (EN 319, 1993) were then determined. Thirty experimental samples were prepared for each investigated property.

In determining the anatomical properties, $5 \mathrm{~cm}$ thick cross-cut disks sawn from the butt and at height of $1,30 \mathrm{~m}$. The samples were taken from wood, boiled in water, stored in $50 \%$ aqueous ethyl alcohol, and sectioned on a sliding microtome. The sections were stained with a combination of safranin and alcian blue combination to allow discernment of pit details. Macerations were prepared by means of Schultze method and stained in safranin (Ives 2001). The data were derived from 25 experimental measurements. This procedure is necessary for IAWA Committee on Nomenclature (IAWA 1964) and 
aggresses closely with the usage of Metcalfe and Chalk (1950). All other wood terms used conform the usage of the IAWA Committee on Nomenclature (IAWA 1964).

The preparation of test samples for detection of chemical properties was carried out following the prescription of TAPPI T 11 M-45 standard (TAPPI 1992). Alcohol-benzene, hot and cold water solubility, solubility in dilute alkali $(1 \% \mathrm{NaOH})$, and lignin content were determined in accordance with TAPPI T 204 cm-9 (TAPPI 1997), TAPPI T 207 om-88 (TAPPI 1988), TAPPI T 212 om-98 (TAPPI 1998), and TAPPI T 222 om-02 (TAPPI 2002), respectively. Holocellulose, cellulose, and $\alpha$-cellulose contents were prepared by the chlorite method (Wise and Karz 1962) and the KürschnerHoffner's nitric acid method (Browning 1967). Ash content was examined by TAPPI test method T 211 om-93 (TAPPI 1993). The acidity of wood was measured in an extract solution made by $3-\mathrm{g}$ wood flour added to 100-ml water and boiled for $30 \mathrm{~min}$ (Prasetya 1989). Amount of condensed tannin (stiasny number) were decided in the light of Tisler et al. (1986). The chemical properties were determined uing three samples.

For the detection of surface roughness, ten experimental samples were used for each type of panels. The test samples were sanded with a sequence of 100- and 150-grit sandpapers. A total of 40 roughness measurements were performed, with 4 measurements for each of 10 samples. Two of the measurements were performed parallel to the sand marks while the other two were performed perpendicular to the sand marks. A Mitutoyo SJ-301surface roughness tester was used to perform roughness test. Three roughness parameters characterized by ISO 4287 (1997), which are average roughness (Ra), mean peak-to-valley height (Rz), and maximum peak-to-valley height (Ry), were considered to assess the surface properties of the samples.

Three samples ( $20 \mathrm{~mm}$ x $20 \mathrm{~mm}$ x $12 \mathrm{~mm}$ ) were randomly taken from each type of particleboard for the determination of formaldehyde emission (FE) by the perforator method based on EN 120-1 (1994) standard.

One-way analysis of variance (ANOVA) was performed to assess the influence of the investigated properties on the quality characteristics of the samples. By using Newman-Keuls's test, significant diffirences between the mean values of the board types were analyzed.

\section{RESULTS AND DISCUSSION}

\section{Anatomical properties}

Table 1 presents the results of anatomical properties of the samples.

Table 1. Anatomical properties.

\begin{tabular}{|c|c|c|c|}
\hline $\begin{array}{c}\text { Raw material grown } \\
\text { region/Wood properties }\end{array}$ & $\begin{array}{c}\text { Fiber length } \\
(\mu \mathrm{m})\end{array}$ & $\begin{array}{c}\text { Thickness of fiber } \\
\text { cell wall }(\mu \mathrm{m})\end{array}$ & $\begin{array}{c}\text { Thickness of trachea } \\
\text { cell wall }(\mu \mathrm{m})\end{array}$ \\
\hline Trabzon & $1230,5(285,11) \mathrm{a}$ & $4,4(1,27) \mathrm{a}$ & $6,6(0,96) \mathrm{a}$ \\
\hline Artvin & $1063,6(195,93) \mathrm{b}$ & $3,9(0,73) \mathrm{b}$ & $5,5(0,70) \mathrm{b}$ \\
\hline
\end{tabular}

Note: The values in parenthesis refer to the standard deviations in the samples: Different letters in the same column indicate that there is a statistical difference at $95 \%$ confidence level.

Ailanthus altissima (Mill.) Swingle wood grown in Trabzon had longer fiber length and thicker fiber and trachea cell walls than those of the wood grown in Artvin. 


\section{Chemical properties}

Table 2 gives the mean values of chemical properties of raw materials.

Table 2. Chemical properties of raw materials.

\begin{tabular}{|c|c|c|}
\hline \multirow{2}{*}{ Chemical properties } & \multicolumn{2}{|c|}{ Raw material grown region } \\
\hline & Trabzon & Artvin \\
\hline $\mathrm{pH}$ & $5,9(0,04) \mathrm{a}$ & $5,8(0,05) \mathrm{b}$ \\
\hline Solubility in dilute alkali $(1 \% \mathrm{NaOH})(\%)$ & $19,7(0,72)$ a & $24,1(0,71) b$ \\
\hline Solubility in alcohol-benzene (\%) & $2,0(0,04) \mathrm{a}$ & $2,4(0,18) b$ \\
\hline Solubility in cold water $(\%)$ & $3,8(0,05)$ a & $6,3(0,06) \mathrm{b}$ \\
\hline Solubility in hot water (\%) & $4,2(0,03) \mathrm{a}$ & $6,6(0,24) b$ \\
\hline Cellulose (\%) & $49,8(0,04) \mathrm{a}$ & $46,5(0,10) b$ \\
\hline Hemicelluloses $(\%)$ & $29,1(0,66) \mathrm{a}$ & $24,4(0,51) b$ \\
\hline Lignin (\%) & $21,3(0,15) \mathrm{a}$ & $24,9(0,11) b$ \\
\hline Ash $(\%)$ & $0,21(0,02) \mathrm{a}$ & $0,35(0,03) b$ \\
\hline $\begin{array}{l}\text { Amount of condensed tannin } \\
\text { (Stiasny number) }(\%)\end{array}$ & $5,0(0,37) \mathrm{a}$ & $6,1(0,55) b$ \\
\hline
\end{tabular}

Note: The values in parenthesis refer to the standard deviations in the samples: Different letters in the same line indicate that there is a statistical difference at $95 \%$ confidence level.

Raw material growth region was determined to be effective on all of the chemical properties. The highest amounts of lignin, ash, condensed tannin and solubility values were found in wood grown in Artvin. Ailanthus altissima (Mill.) Swingle wood grown in Trabzon had higher amounts of cellulose and hemicelluloses than those of the wood grown in Artvin.

\section{Surface properties}

Table 3 presents the roughness values of the particleboards.

Table 3. Average roughness values of the particleboards.

\begin{tabular}{|c|c|c|}
\hline \multirow{2}{*}{ Surface properties } & \multicolumn{2}{|c|}{ Panel types } \\
\cline { 2 - 3 } & Trabzon & Artvin \\
\hline $\operatorname{Ra}(\mu \mathrm{m})$ & $6,2(1,70) \mathrm{a}$ & $53,0(1,48) \mathrm{b}$ \\
\hline $\operatorname{Ry}(\mu \mathrm{m})$ & $45,0(12,38) \mathrm{a}$ & $\mathrm{b}$ \\
\hline $\operatorname{Rz}(\mu \mathrm{m})$ & $27,9(5,67) \mathrm{a}$ & $33,6(4,54) \mathrm{b}$ \\
\hline
\end{tabular}

Note: The values in parenthesis refer to the standard deviations in the samples: Different letters in the same line indicate that there is a statistical difference at $95 \%$ confidence level.

Raw material growth region statistically affected the surface quality of particleboard. Panels made from wood grown in Artvin had worse surface quality properties than those of panels made from wood grown in Trabzon. Extractives and ash negatively affect the bonding of wood. Poor bonding increases the surface roughness of particles (Lehman and Geimer 1974). Related to this, surface roughness values are increased. As can be seen in Table 2, wood grown in Artvin had higher solubility and amount of ash than wood grown in Trabzon. 


\section{Physical and mechanical properties and formaldehyde content} 4.

The physical and mechanical properties and formaldehyde emission values are presented in Table

Table 4. Average mechanical and physical properties and formaldehyde content of particleboards.

\begin{tabular}{|c|c|c|}
\hline \multirow{2}{*}{ Property } & \multicolumn{2}{|c|}{ Panel types } \\
\cline { 2 - 3 } & Trabzon & Artvin \\
\hline MOR $(\mathrm{MPa})$ & $14,3(2,34) \mathrm{a}$ & $12,9(2,87) \mathrm{b}$ \\
\hline MOE $(\mathrm{MPa})$ & $2025,1(223,97) \mathrm{a}$ & $1905,2(160,34) \mathrm{b}$ \\
\hline IB $(\mathrm{MPa})$ & $0,44(0,080) \mathrm{a}$ & $0,35(0,035) \mathrm{b}$ \\
\hline TS $(\%)^{\mathrm{a}}$ & $15,2(0,59) \mathrm{a}$ & $13,2(0,71) \mathrm{b}$ \\
\hline TS $(\%)^{\mathrm{b}}$ & $22,5(0,29) \mathrm{a}$ & $20,6(0,73) \mathrm{b}$ \\
\hline FE $(\mathrm{mg} \mathrm{CHOH})$ & $6,2(0,10) \mathrm{a}$ & $5,8(0,12) \mathrm{b}$ \\
\hline
\end{tabular}

Note: The values in parenthesis refer to the standard deviations in the samples: Different letters in the same line indicate that there is a statistical difference at $95 \%$ confidence level.

a: After $2 \mathrm{~h}$ immersion, ${ }^{\mathrm{b}}$ : After $24 \mathrm{~h}$ immersion.

Based on EN 312 (2005), the minimum requirements for MOR are 12,5 MPa and 13,0 MPa for general uses and interior application (including furniture), respectively, while the minimum MOE for interior application is $1800 \mathrm{MPa}$. The results revealed that the IB of the panels ranged from 0,35 to $0,44 \mathrm{MPa}$. The minimum requirements of IB for general purpose and furniture production are 0,28 $\mathrm{MPa}$ and $0,40 \mathrm{MPa}$ according to EN 312 standard, respectively. Panel from wood grown in Trabzon had the required levels of MOR, MOE and IB for furniture production. The results showed that panels produced from wood grown in Artvin could be used for general purpose. On the other hand, it is possible to say that the produced boards did not meet the requirements of EN 312 for the TS because no wax or other water-repellent agents were used in the production process. The maximum allowable value of the formaldehyde content for $\mathrm{E}_{1}$ quality is $8 \mathrm{mg} \mathrm{CHOH} / 100 \mathrm{~g}$ dry sample (EN 120.-1, 1994). All panels met the required criteria of formaldehyde emission.

The test panels manufactured from wood grown in Trabzon had higher mechanical properties properties (MOR, MOE, and IB) than those of the panels manufactured from wood grown in Artvin. Fiber length, thicknesses of fiber and trachea cell walls of wood affect substantially the strength properties of particleboard. Longer fibers and, thicker fiber and trachea cell walls cause tighter and more compact wood structure and positively affect the strength properties (Baharoglu et al. 2013). It can be seen from Table 1 that wood grown in Trabzon had longer fiber length and thicker fiber and trachea cell walls than those of wood grown in Artvin. Cellulose is the skeleon of wood. High amount of cellulose improves the mechanical properties of wood (Ors and Keskin 2001). As can be seen in Table 2, wood grown in Trabzon had higher amount of cellulose than wood grown in Artvin. Wood grown in Artvin had higher solubility values than wood grown in Trabzon (as could be seen in Table 2). Higher amount of extractives in wood causes lower values of mechanical properties because the extractives adversely affect the strength of the adhesive bond. The reason for the high solubility is the high amount of extractives in wood. Extractives negatively affect adhesive bonding and adhesion. Extractives create air bubbles during hot pressing. Air bubbles cause weakened glue bonds (Ayrılmış and Winandy 2009). The ash content of wood grown in Artvin was substantially higher than that of wood grown in Artvin (as could be seen in Table 2). It is important to state that ash has no wettability. This leads to a reduction in the bond quality of the water based formaldehyde resins (Grigoriou 2003, Kim et al. 2006). This stuation can be a reason for the lower bending properties and IB strength of the parnels produced from wood grown in Artvin. 
The results show that particleboards produced from wood grown in Artvin had lower TS values than those of the particleboards produced from wood grown in Trabzon. This situation can be clarified by the chemical and anatomical changes in the wood grown in different regions. Higher amounts of lignin and extractives, and lower amounts of cellulose and hemicelluloses were detected in wood grown in Artvin (Table 2). The polysaccharides components of wood cell walls, in particular hemicelluloses, are highly hydrophilic, whereas lignin and extractives re more hydrophobic. A reason for lower TS of the panels could be higher lignin and extractive amounts of the wood grown in Artvin (Borgin and Corbett 1974, Marshall et al. 1974, Bariska and Pizzi 1986, Vanleemput et al. 1987, Pasillias and Voulgaridis 1999). Wood grown in Trabzon had thicker fiber and trachea cell walls (Table 1). The water absorbs to $\mathrm{OH}$ groups in the cell wall. Thicker cell wall consists of higher amount of cellulose (Baharoglu et al. 2013).

The formaldehyde emission of the panels produced from wood grown in Artvin was substantially lower than that of the panels produced from wood grown in Trabzon. This is due to chemical differences in wood grown in different regions. A higher stiasny number (condensed tannin) is associated with a higher amount of polyphenolic extractive content in the furnish. Polyphenolic extractives reduce the formaldehyde emission (Wisherd and Wilson 1979, Yusuf 1996, Raffael et al. 2000).

\section{CONCLUSIONS}

In this work, the effect of raw material growth region on the quality features of particleboards was investigated. The results revealed that Ailanthus altissima swingle trees can be used to produce particleboards. The raw material growth region was a major parameter influencing all characteristics of the particleboards. The best strength and surface quality properties were obtained from the particleboards produced from wood grown in Trabzon. However, the TS and FE of particleboards produced from wood grown in Artvin were significantly lower than those of the particleboards produced from wood grown in Trabzon. From the results of the current study, it is possible to say that the chemical and anatomical differences of the wood grown in different regions influence all quality properties of particleboards.

\section{REFERENCES}

Altgen, D.; Bellmann, M.; Wascher, R.; Viöl, W.; Mai, C. 2015. Enhancing mechanical properties of particleboards using plasma treated wood particles. European Journal of Wood and Wood Products 73: $219-223$.

Ayrilmis, N.; Buyuksari, U.; Avci, E.; Koc, E. 2009. Utilization of pine (Pinus pinea L.) cone in manufacture of wood based composite. Forest Ecology and Management 259: 65-70.

Ayrilmis, N.; Lee, Y.K.; Kwon, J.H.; Han, T.H.; Kim, H.J. 2016. Formaldehyde emission and VOCs from LVLs produced with three grades of urea-formaldehyde resin modified with nanocellulose. Building and Environment 97: 82-87.

Ayrilmis, N.; Winandy, J.E. 2009. Effect of heat treatment on surface characteristics and adhesive bonding performance of MDF. Materials and Manufacturing Process 24: 594-599. 
Baharoglu, M.; Nemli, G.; Sari, B.; Birturk, T.; Bardak, S. 2013. Effects of anatomical and chemical properties of wood on the quality of particleboard. Composites Part B: Engineering 52: 282285 .

Balanchet, P.; Cloiter, A.; Riedl, B. 2000. Particleboard produced from hammer milled black spruce bark residues. Wood Science and Technology 34: 11-19.

Bariska, M.; Pizzi, A. 1986. The interaction of polyflavonoid tannins with wood cell walls. Holzforschung 40(5): 299-302.

Boon, J.G.; Hashim, R.; Sulaiman, O.; Hiziroglu, S.; Sugimoto, T.; Sato, M. 2013. Influence of processing parameters on some properties of oil palm trunk binderless particleboard. European Journal of Wood and Wood Products 71: 583-589.

Borgin, K.; Corbett, K. 1974. The hydrophobic properties of wattle bark extractives. Wood Science and Technology 8(2): 138-147.

Browning, B.L. 1967. Methods of wood chemistry. New York: Interscience, vol. 1-2.

European Committee for Standardization. EN. 1994. Determination of formaldehyde content in fiberboard by using perforator method. EN 120-1. Brussels.

European Committee for Standardization. EN. 1993. Wood based panels, determination of modulus of elasticity in bending and bending strength. EN 310. Brussels.

European Committee for Standardization. EN. 2005. Particleboards-specifications. EN 312. Brussels-Belgium.

European Committee for Standardization. EN. 1993. Particleboard and fiberboards, determination of swelling in thickness after immersion in water. EN 317. Brussels.

European Committee for Standardization. EN. 1993. Particleboard and fiberboards, determination of tensile strength perpendicular to the plane of the board. EN 319. Brussels.

Fernandez, F.G.; Esteban, L.G.; De Palacios, P.; Navarro, N.; Conde, M. 2008. Prediction of standard particleboard mechanical properties utilizing an artificial neural network and subsequent comparison with a multivariate regression model. Investigación Agraria: Sistemas y Recursos Forestales 17: 178-187.

Ghalehno, M.D.; Nazerian, M.; Bayatkashkooli, A. 2011. Influence of utilization of bagasse in surface layer on bending strength of three-layer particleboard. European Journal of Wood and Wood Products 69: 533-535.

Grigoriou, A.H. 2003. Waste paper wood composites bonded with isocynate. Wood Science and Technology 37: 79-89.

Hiziroglu, S.; Graham, M. 1998. Effect of press closing time and target thickness on surface roughness of particleboard. Forest Products Journal 48 (3): 50-54. 
Hiziroglu, S.; Jarusombuti, S.; Fuengvitat, V. 2004. Surface characteristics of wood composites manufactured in Thailand. Building and Environment 39: 1359-1364.

International Association of Wood Anatomists. IAWA. 1964. Committee on nomenclature. Winterthur: Multi lingual glossary of terms used in wood Anatomy.

International Organization for Standardization. ISO. 1997. International standard geometrical products specifications (GPS) surface texture: profile method terms, definitions, and surface texture parameters. ISO 4287. Geneva

Ives, E. 2001. A guide to wood microtermy: making quality microslides of wood sections. Lincolnshire (UK): Savona Books.

Kim, S.; Kim, H.J.; Lee, H.H. 2006. Effect of bio-scavengers on the curing behavior and bonding properties of melamine formaldehyde resins. Macromolecular Materials and Engineering 291: 10271034.

Kord, B.; Roohani, M.; Kord, B. 2015. Characterization and utilization of reed stem as a lignocellulosic resource for particleboard production. Maderas-Cienc Tecnol 17(3): 517-524.

Kord, B.; Zare, H.; Hosseinzadeh, A. 2016. Evaluation of the mechanical and physical properties of particleboard manufactured from canola (Brassica napus) straws. Maderas-Cienc Tecnol 18(1): 9-18.

Lehman, W.F.; Geimer, R.L. 1974. Properties of Structural ParticleboardsFrom Douglas-Fir Forest Residues. Forest Products Journal 24 (10): 17-25.

Liu, Y.; Shen, J.; Zhu, X.D. 2015. Evaluation of mechanical properties and formaldehyde emissions of particleboards with nanomaterial-added melamine-impregnated papers. European Journal of Wood and Wood Products 73: 449-455.

Marshall, S.W.; Ifju, G.; Johnson, J.A. 1974. The role of extractives in the hydrophbic behavior of loblollypine rhytidome. Wood and Fiber Science 5(4): 353-363.

Melo, R.R.; Stangerlin, D.M.; Santana, R.R.C.; Pedrosa, T.D. 2015. Decay and termite resistance of particleboard manufactured from wood, bamboo and rice husk. Maderas-Cienc Tecnol 17(1): 55-62. 1 .

Metcalfe, C.R.; Chalk, L. 1950. Anatomy of dicotyledons. London: University Press. $1^{\text {st }}$ edn. Vol.

Moubarik, A.; Mansouri, H.R.; Pizzi, A.; Charrier, F.; Allal, A. 2013. Bertrand charrier corn flour-mimosa tanin-based adhesives without formaldehyde for interior particleboard Production. Wood Science and Technology 47: 675-683.

Muhcu, S.; Nemli, G.; Ayrılmıs, N.; Bardak, S.; Baharoğlu, M.; Sarı, B.; Gerçek, Z. 2015. Effect of log position in European Larch (Larix decidua Mill.) tree on the technological properties of particleboard. Scandinavian Journal of Forest Research 30 (4): 357-362. 
Nazerian, M.; Beyki, Z.; Gargarii, R.M.; Kool, F. 2016. The effect of some technological production variables on mechanical and physical properties of particleboard manufactured from cotton (Gossypium hirsutum) stalk. Maderas-Cienc Tecnol 18(1): 167-178.

Nemli, G.; Demirel, S. 2007. Relationship Between the Density Profile and the Technological Properties of the Particleboard Composite. Journal of Composite Materials 41(15): 2007.

Nemli, G.; Ozturk, I.; Aydin, I. 2005. Some of the parameters influencing surface roughness of particleboard. Building and Environment 40: 1337-1340.

Ors, Y.; Keskin, H. 2001. Wood Technology. Kosgeb Publications. 975-7608-87-4. Ankara, Turkey (in Turkish).

Pasillias, C.N.; Voulgaridis, E.V. 1999. Water repellant efficiency of organic solvent extractives from aleppo pine leaves and bark applied to wood. Holzforschung 53: 151-155.

Prasetya, B. 1989. The investigations on the barks of various tree species [Bachelor thesis on the afforestation of tropic and subtropic regions]. Gottingen: Forestry faculty, University of Gotingen Georg-August.

Que, Z.; Furunoa, T.; Katoha, S.; Nishinob, Y. 2007. Effects of urea formaldehdye resin mole ration on the properties of particleboard. Building and Environment 42 (3): 1257-1263.

Raffael, E.; Dix, B.; Okum, J. 2000. Use of spruce tanin as a binder in particleboards and MDF. Holz als Roh- und Werkstoff 58: 301-305.

Technical Association of Pulp and Paper Industry. TAPPI. 1992. Sampling ad preparing wood for analysis. TAPPI T 11 M-45. TAPPI test methods. Atlanta (GA): TAPPI Press.

Technical Association of Pulp and Paper Industry. TAPPI. 1997. Solvent extractives ofwood and pulp. T $204 \mathrm{~cm}-97$. TAPPI test methods. Atlanta (GA): TAPPI Press.

Technical Association of Pulp and Paper Industry TAPPI. 1988. Water solubility of woodand pulp. TAPPI T 207 om-88.TAPPI test methods, Atlanta (GA): TAPPI Press.

Technical Association of Pulp and Paper Industry. TAPPI. 1993. Ash in wood, pulp, paper and paperboard. T 211 om-93.TAPPI test methods. Atlanta (GA): TAPPI Press.

Technical Association of Pulp and Paper Industry. TAPPI. 1998. One percent sodiumhydroxide solubility of wood and wood pulp. T 212 om-98. TAPPI testmethods. Atlanta (GA): TAPPI Press.

Technical Association of Pulp and Paper Industry. TAPPI. 2002. Acid-insoluble lignin inwood and pulp. T 222 om-02. TAPPI test methods. Atlanta (GA): TAPPI Press.

Tisler, V.; Galla, E.; Pulkinen, E. 1986. Fractination of hot water extract from Picea abies Karst. bark. Holz als Roh- und Werkstoff 44: 427-431. 
Vanleemput, M.; Boye, C.; Logtenberg, E.H.P. 1987. Upgrading on beech by physicochemical treatments to ensure stability, durability and esthetic look. Wood as Renawable Raw Material Proceedings. Seminar on Wood Technology. Munich, p.14-18.

Wise, E.L.; Karz, H.L. 1962. Cellulose and hemicelluloses. In: Earl Libby C, editor. Pulp and paper science and technology. New York: McGray Book Com, p. 55-73.

Wisherd, K.D.; Wilson, B. 1979. Bark as a supplement to wood furnish for particleboard. Forest Products Journal 29 (2): 35.40.

Yusuf, S. 1996. Properties enhancement of wood by cross lingkink formation and its application to the reconstituted wood products. $\mathrm{PhD}$ thesis. Kyoto University. Kyoto, Japan.

Zhang, Y.; Luo, X.; Wang, X.; Qian, K.; Zhao, R. 2007. Influence of temperature on formaldehyde emission parameters of dry building materials. Atmospheric Environment 41: 3203-3216. 